\title{
Function of Nonverbal Signs in Balia Rituals The Kaili ethnic in Palu, Indonesia
}

\author{
Agustan $^{1 *} \quad$ Setya Yuwana ${ }^{2} \quad$ Budinuryanta Yohanes ${ }^{3}$ \\ The State University of Surabaya, Surabaya, Indonesia
}

\begin{abstract}
The purposes of this study are to find and describe the function of nonverbal signs in Balia ritual in Central Sulawesi, which are found in (1) equipment, (2) attribute, (3) instrument, (4) color, and (5) motion. The function of nonverbal sign on attribute is found in pajama (men's clothing), siga (men's headband), silu (women's headband), shawl, fan, babe (a type of machete used by men), which includes two functions of the sign, which are the symbolsinsign and icon-sinsign. The function of nonverbal sign of the instrument are the kakula (a type of gamelan), gong, gimba (a type of drum), lalove (Kaili's flute) including three sign functions, namely icon-qualisign-inconicsinsign, qualisign-inconicsinsign, and symbol-inconicsinsign. The function of nonverbal sign on color is found in red, yellow, white, and black colors that include two sign functions, namely icon-symbol-qualisign and symbolqualisign. The function of nonverbal sign on motion is found in meaju, motaro, raego, motaro, and salonde, including one sign function, namely the rhematic symbol-iconic sinsign. This research is a descriptive qualitative research with ethnographic and interdisciplinary approaches. The research data was in the formof photo documentation and recordings and facts at the research location. The data collection activities were carried out using observation techniques, field notes, in-depth interviews, and recording/documentation. The data analysis technique used objective hermeneutics which was divided into two procedures, namely (1) series analysis and (2) detailed analysis.For the validity of the data, triangulation was carried out at each stage of the research, research tools, and clarification of research findings to informants namely the balia ritual leader and followers of the balia ritual, focus group discussions, and external auditors who knows deeply about the balia ritual. The findings of this study are the function of nonverbal signs in the Kaili ethnic balia ritual in Palu-Indonesia which is found in (1) equipment, (2) attribute, (3) instrument, (4) color, and (5) motion. Theoretically, this study strengthens pragmasemiotics because the findings of this study indicate the function of nonverbal signs in balia rituals in the context of nonverbal language. In practical terms, these findings are useful for universities related to teaching pragmatics and semiotics that develop interdisciplinary science by integrating two theories, namely pragmatics and semiotics into pragma-semiotics.
\end{abstract}

Keywords: function, nonverbal signs, balia ritual, pragma-semiotics

DOI: $10.7176 /$ RHSS/10-24-08

Publication date: December $31^{\text {st }} 2020$

\section{Introduction}

The Kaili ethnic balia ritual was known as non-medical treatment before the existence of medical science. This ceremony is believed by the Kaili ethnic community to get guidance and assistance from ancestors in curing diseases that attack the human body. The balia ritual which is full of signs is a legacy of the Kaili ethnic ancestors that has been preserved in the Kaili people in Central Sulawesi from generation to generation. It includes signs of verbal and nonverbal language inside of it. Verbal language signs come from mantras and nonverbal language signs come from equipment, attribute, instrument, color and movement.

The pragmasemiotic study in the transformation of the earth mantra sign of the Kaili ethnic balia ritual in Palu is an original research based on research from experts such as Silverstein, Duranti, Derrida, Urban, Staehr, Verschueren, Hjelmslev, Fernández, Blunk, and Alatas who have conducted several studies about meta sign. Urban's (2006) research on meta-semiotics is a series of developing the concept of the Peirce's trichotomy hierarchy sign which includes icons, indexes and symbols that are closely related to the study of symbols and context studies by Silverstein on semiosis and meta-pragmatic discourses that are related in context.

Analyzing the function of nonverbal signs in balia rituals is not enough to only use semiotic theory, because the interpretation of the signs in the mantra is complex and contextual, so it is appropriate to integrate the two theories into a unified whole, namely pragma-semiotics derived from the development of sign studies and context studies. Nonverbal signs in balia rituals can be found in equipment, attribute, instrument, color, and movement which are closely related to the phenomenon of signs and contexts that are formed from sociocultural and supernatural processes.

Signs are basically all things that can be used as a signifier and as a sign (signified). In this case, the signifier is a symbol that serves to explain the sign as its meaning. Saussure defines semiotics as the study of the role of signs as part of social life. This opinion is in line with the concept of sign developed by Peirce in the form of metasign which became known as trichotomy; icons, indexes and symbols. In the balia ritual, this concept is a new thought as an elaboration of semiotic and pragmatic concepts that focus on nonverbal signs. This arises as a result 
of the influence of other socio-cultural aspects which then rise the categories of nonverbal signs originating from outside the mantra.

If we look at the concept of the Saussure sign as an inseparable unity between the signifier and the signified and its relationship with Peirce's trichotomy meta-sign, this is closely related to significant semiotic thinking and communication semiotics in seeing the sign as a unitary form that is flexible in its context. This is in line with Saussure's thinking as a pioneer of the concept that social conventions in language communities that functions concretely to regulate the meaning of a sign (Fiske, 1990: 15). This opinion supports the idea that one word has a certain meaning due to social agreement among the language-user community (Culler, 1976: 19).

The study of Saussure's sign development is stated by Fiske (1990, p. 15) that semiotics is the study of the role of signs as part of social life. From this opinion, it can be concluded that a sign is a relation that is part of social life and applicable social rules. The social convention referred to as Saussure is a sign system and an interconnected social system. This thinking is the development of the concept of the unity of form and meaning, namely signifier and signified that can be synchronized with the development of Peirce's thought.

Peirce's concept of trichotomy is an empirical study of the development of semiotics into meta-semiotics. His rationale was also influenced by Kant's explorations. Peirce views the human ability to relate to external reality as a result of a complex layered sign process in the form of icons, indexes and symbols (Urban, 2006, p. 89).

The balia ritual produces nonverbal signs due to the dynamics of the culture of the supporting community, in this nonverbal sign there is an icon that shows a relationship between the signifier and the signified which is similar (similitude), the index explains the relationship between the signifier and the signified which is causal, while the symbols explain the relationship between the signifier and the signified that are conventional.

This concept is in line with the synchronization of Saussure's structural semiotic thinking and Peirce's trichotomy in the development of semiotic and pragmatic studies as a strengthening of thought to see the similarities of the concepts in order to minimize theoretical conflicts. This opinion can develop into metasemiotic and meta-pragmatic activities which refer to nonverbal signs and those associated between the both. Pragmasemiotics are present as part of metapragmasemiotics which are used to assess the transformation of verbal signs. In this study, the context is focused on non-narrative or non-verbal. Signs and their contexts are an inseparable language system, like fire from its hot state, or snow from its cold state. Fire and snow are signs, while hot and cold conditions are the context. Thus what is found in the nonverbal sign of the balia ritual is interrelated between the nonverbal signs found in equipment, attribute, instrument, color, and movement.

Analysis of the function of nonverbal signs in balia rituals in pragma-semiotic studies is in line with Hübler (2007, p.108) regarding gestural behavior or gestures as an important aspect in studying language signs that cause impressions in an interaction process. Also related to the opinion of Badriah (2011) that verbal and nonverbal language is used and how the language functioned, in the sense that the sign and context cannot be separated as a system. A language has different purposes in different contexts; Nonverbal language in balia rituals has a different purpose fromnonverbal language in daily activities.

This thought strengthens the relationship between context interpretation as a pragmatic study and sign interpretation as a semiotic study that has the same importance in exploring signs and their context. This cannot be separated because the integration of this study will explain the nonverbal sign and the context of the sign in terms of its function. Nonverbal sign functions are categorized based on the Peirce sign classification including qualisign, inconicsinsign, legisign, symbol, rhematic symbol, icon, and rheme. The categories of sign transformation that are found cannot be separated from the essence of balia ritual as a context that presents nonverbal symbols and icons that can develop interpretations of the signs produced in these ritual activities in order to strengthen the dimensions of their supernatural signs. To realize a complete study, the application of pragma-semiotics study becomes a form of the novelty of the theory required in this study.

The thought of pragma-semiotics is based on the functioning of the nonverbal signs contained in the baliaritual after a pre-survey is carried out. The results of the survey found three contextual aspects of signs in the balia ritual, namely (1) nonverbal signs as signifier of a traditional context, (2) nonverbal signs as signifier of aesthetic context, and (3) nonverbal signs as signifier of value context. The three signifier of the context reinforce the manifestation of the nonverbal sign's function in the balia ritual.

This research includes qualitative research with a realistic ethnographic approach, which is research conducted in certain cultural groups for a long time to obtain data naturally without taking sides with the research subject (Creswell, 2014: ix). Research data on nonverbal signs in balia rituals were obtained from informants, namely the indigenous Kaili ethnic group aged 42 to 75 years. Data collection was carried out by (1) observation, (2) recording, (3) in-depth interviews, and (4) documentation. The data collected were analyzed using an objective hermeneutic model which was divided into two procedures, namely (1) serial analysis and (2) detailed analysis.

Sequential analysis is selecting and breaking the text into smaller units and interpreting it to find clarity of meaning contained in the text. Detailed analysis is to divide the text in sequence and separate into sections and subsections and then interpret it in order to find meaning contextually by considering internal and external meanings (Titscher, 2009). 


\section{The Function of Nonverbal Signs in Balia Rituals}

The findings of the function of nonverbal signs in balia rituals are found in (1) equipment, (2) attribute, (3) instrument, (4) color, and (5) movement. The nonverbal sign function on equipment is found in fire, coconut, banana, sugar cane, tampi(spear), cow/goat, chicken, egg, sticky rice, areca nut, gambier, tobacco, lime, betel, guma (machete), bantaya, incense, tray, flag made of mbesa cloth, flag of white cloth, and kalioavo (shield). The function of nonverbal signs on attribute is found in pajama (men's clothing), siga (men's headband), silu (women's headband), shawl, fan, babe (a type of machete used by men). The nonverbal sign functions of the instrument are the kakula (a type of gamelan), gong, gimba (a type of drum), lalove (a Kaili flute). The function of nonverbal signs on color is found in red, yellow, white, black. The function of nonverbal signs on motionis found in meaju, motaro, raego, motaro, and salonde.

\subsection{Nonverbal Signs Function of Balia Ritual on Equipment}

The function of the nonverbal signsof balia ritual on equipment can be seen in the following data: Table 1 The functions of Nonverbal Signs on Equipment

\begin{tabular}{|l|l|l|}
\hline \multicolumn{1}{|c|}{ Data Code } & \multicolumn{1}{c|}{$\begin{array}{c}\text { Nonverbal Sign } \\
\text { (Equipment) }\end{array}$} & \multicolumn{1}{c|}{ Sign Function } \\
\hline Nvp1 & Tha blazing fire & Symbol- Qualisign \\
\hline Nvp2 & The sprouting coconut & Rhematic symbol \\
\hline Nvp3 & Banana stem & Symbol- Dicent Sign \\
\hline Nvp4 & Sugar cane stem & Rhematic symbol \\
\hline Nvp5 & Tampi (Spear) & Inconic Sinsign \\
\hline Nvp6 & Cow/goat & Dicent Sign \\
\hline Nvp7 & Chicken & Dicent Sign \\
\hline Nvp8 & Banana & Rhematic symbol \\
\hline Nvp9 & Areca nut & Symbol- Dicent Sign \\
\hline Nvp10 & Gambier & Symbol- Dicent Sign \\
\hline Nvp11 & Sticky rice & Symbol-Qualisign \\
\hline Nvp12 & Betel & Symbol- Dicent Sign \\
\hline Nvp13 & Kaliavo (Shield) & Inconic Sinsign \\
\hline Nvp14 & Guma (Machete) & Inconic Sinsign \\
\hline Nvp15 & Incense & Dicent Sign \\
\hline Nvp16 & Umbrella & Symbol-Sinsign \\
\hline
\end{tabular}

Description: Nvp = Nonverbal perlengkapan (Nonverbal equipment in English)

The description of the nonverbal sign function in table 1 is:

Nvp1- The blazing fire serves as a sign that triggers the spirit of the Sando followers to ignite the evil traits that still remain in the heart and mind.

Nvp2- Coconut that grows shoots function to show purity and grow naturally.

Nvp3- The sprouting banana stem in the baliaritual is a sign that serves to symbolize sustainable growth.

Nvp4- Sugarcane in balia ritual is a nonverbal sign that functions as a symbol that shows something sweet.

Nvp5- Tampi or spear is a sign that serves as a symbol to spear evil spirits that disturb and cause pain.

Nvp6- Cow or goat is a sign that serves to signify or declare sacrifice

Nvp7- Chicken is a sign that serves to show the validity of the ritual.

Nvp8- Banana is a sign that serves as a treat for the sweetness of the heart of the family that holds the balia ritual Nvp9- Areca nut is a sign that functions to prevent and fight various types of diseases.

Nvp10- Gambier is a sign that serves as a defense for the body and mind from evil influences.

Nvp11- Sticky rice is a sign that functions as a symbol of strength that unites and bonds kinship and brotherhood relations that have been disturbed due to slander and negative thoughts that arise by the presence of a disease that come a sign that the cause is known.

Nvp12- Betel serves as a marker of purity, repelling evil intentions.

Nvp13- Kaliavo serves as a symbol of protection from various diseases and malicious intent.

Nvp14- Guma serves as a symbol of strength and strength to ward off enemies or evil traits.

Nvp15- Incense serves as a symbol of a link between ancestors and their descendants or between the real world and the supernatural.

Nvp16- Umbrella serves as a symbol of protection and protection for the descendants of balia blood so that they are protected from evil intentions and black magic that can harm their children and grandchildren.

\subsection{Nonverbal Signs Function of Balia Ritual on Attribute}

The function of the balia ritual nonverbal sign can be seen in the following data: 
Table 2 The functions of Nonverbal Signs on Attribute

\begin{tabular}{|c|c|c|}
\hline Data Code & $\begin{array}{c}\text { Nonverbal Sign } \\
\text { (Attribute) }\end{array}$ & Sign Function \\
\hline Nval & Pajama (Men's clothing) & Symbol-Sinsign \\
\hline Nva2 & Siga(Men's headband) & Icon-Sinsign \\
\hline Nva3 & Silu(Women's headband) & Icon-Sinsign \\
\hline Nva4 & Shawl & Symbol-Sinsign \\
\hline Nva5 & Fan & Symbol-Sinsign \\
\hline Nva6 & Babe (Men's machete) & Icon-Sinsign \\
\hline
\end{tabular}

Description: Nva = Nonverbal attribute

The description of the nonverbal sign function in table 2 is:

Nva1-Pajama is the traditional clothing of the Kaili parents used for men. Pajama is to function as a sign of respect for future ancestors during the balia ritual.

Nva2- Siga is a male head covering for the Kaili ethnic group that functions as a symbol of lording towards the ancestors and guests who witness the balia ritual procession.

Nva3-Silu is a bark cloth used as a head covering for women in the Kaili ethnic group, which functions as a sign of glorification for female ancestors who will come during the balia ritual.

Nva4- Shawl made of silk cloth are used for dancing by women as a curtain covering women's necks which serves as a sign of protection from evil influences that will penetrate through the neck and throat.

Nva5- The fan used for dancing by women serves as a symbol of bondage, joy, gentleness, and coolness.

Nva6- Babe is a dagger worn by men in the Kaili ethnic group which serves as a symbol of courage, masculinity, and agility in acting to stifle evil influences.

\subsection{Nonverbal Signs Function of Balia Ritual on Instrument}

The function of the balia ritual nonverbal sign on the instrument is described as follows:

Table 3 The functions of Nonverbal Signs on Instrument

\begin{tabular}{|l|l|l|}
\hline \multicolumn{1}{|c|}{ Data Code } & \multicolumn{1}{|c|}{$\begin{array}{c}\text { Nonverbal Sign } \\
\text { (Instrument) }\end{array}$} & \multicolumn{1}{c|}{ Sign Function } \\
\hline Nvi1 & Kakula & Icon-Qualisign-Inconic Sinsign \\
\hline Nvi2 & Lalove & Icon-Qualisign-Inconic Sinsign \\
\hline Nvi3 & Gimba & Qualisign-Inconic Sinsign \\
\hline Nvi4 & Gong & Symbol-Inconic Sinsign \\
\hline
\end{tabular}

Description: Nvi = Nonverbal instrument

The description of the nonverbal sign function in table 3 is:

Nvi1- Kakula or kakula nubalia is a musical instrument that resembles a gamelan, which functions as a sign of the start of the Kaili ethnic traditional procession so that people come voluntarily to the place where the balia ritual or Kaili traditional ceremony takes place.

Nvi2- Lalove is an ethnic Kaili flute functioned to mark the arrival and return of ancestral spirits. The lalove blow varies with different functions. Momperata blow (inviting to come) is a sign that functions to summon spirits. The mompotatausi blow functions as a sign to tell the spirits that come not to cry or complain, because generally the spirits who come will cry and complain. The mom pakaondo blow serves as a sign to calm the spirits that are restless and haunt. The mosalondeblow serves as a sign to create and accompany the dancing spirit. And popanjili blow serves as a sign to return the spirit to its place of origin.

Nvi3- Gimba is a musical instrument of the Kaili ethnic group which functions to mark the start of the balia ritual and other Kaili traditional rituals. The beat of the gimbakandajojo or (a fast rhythmic punch) serves as a sign to summon and bring back ancestral spirits. The Tutupendo wasp is performed when the spirit is Motaro (dancing). The wasp of the Tangguladofunctions as a sign that calls for continuing the Motaro process until all the balia participants feel happy.

Nvi4- Gong is a musical instrument that is beaten and used to echo to the public about the balia ritual. Gong is also used to maintain the rhythm when the balia performer is possessed by an ancestral spirit, so that it does not cause movements that can damage or injure others. 


\subsection{Nonverbal Signs Function of Balia Ritual on Color}

The function of the nonverbal ritual balia sign on color is described as follows:

Table 4 The functions of Nonverbal Signs on Color

\begin{tabular}{|c|c|c|}
\hline Data Code & $\begin{array}{c}\text { Nonverbal Sign } \\
\text { (Color) }\end{array}$ & Sign Function \\
\hline Nvw1 & Yellow & Icon-Symbol-Qualisign \\
\hline Nvw2 & Red & Icon-Symbol-Qualisign \\
\hline Nvw3 & White & Symbol-Qualisign \\
\hline Nvw4 & Black & Symbol-Qualisign \\
\hline
\end{tabular}

Description: Nvw = Nonverbal warna (Nonverbal color in English)

The description of the nonverbal sign function in table 4 is:

Nvw1- The yellow color found on clothes or other attributes is a sign that functions as a symbol of light because what will enter the body of the Sando (balia shaman) is the spirit of the ancestors who are believed to be light or illuminating light. The yellow color is also a sign that serves as a symbol of friendship, prosperity, health to foster a feeling of calm and peace. The yellow color is also a symbol of To Manuru (heavenly descent), which means a person who is sent to transform into a yellow bamboo that transforms into a human.

Nvw2- The color red is the color that serves as a symbol of courage and determination like a burning fire, and the bigger the flame the harder it is to put out.

Nvw3- The white color in the balia ritual is a sign that serves to symbolize purity, sincerity, and goodwill of the balia family in receiving advice and treatment from Sando.

Nvw4- The black color symbolizes the depth of knowledge and power of spirits from the middle realm and the sacredness of the balia in a community of believers.

\subsection{Nonverbal Signs Function of Balia Ritual on Motion}

The function of the balia ritual nonverbal sign on motion is described as follows:

Table 5 The functions of Nonverbal Signs on Motion

\begin{tabular}{|c|c|c|}
\hline Data Code & $\begin{array}{c}\text { Nonverbal Sign } \\
\text { (Motion) }\end{array}$ & Sign Function \\
\hline Nvg1 & Meaju & Rhematic symbol-iconic sinsign \\
\hline Nvg2 & Raego & Rhematic symbol-iconic sinsign \\
\hline Nvg3 & Motaro & Rhematic symbol-iconic sinsign \\
\hline Nvg4 & Salonde & Rhematic symbol-iconic sinsign \\
\hline
\end{tabular}

Description: Nvg = Nonverbal gerak (Nonverbal motion in English)

The description of the nonverbal sign function in table 5 is:

Nvg1- Meaju is a sign that functions as a spear that is carried out to spear animals during the balia process. The spear of animals serves as a sign of "killing" the animal traits in humans.

Nvg2-Raego is a movement performed during the balia ritual procession as a sign that functions to encircle and protect patients from the threat of disease and witchcraft. The movement of the raego also serves as a sign of strengthening and strengthening the lines/groups of balia so as not to be easily entered by evil influences.

$\mathrm{Nvg3-Motaro}$ is a rough processional movement with free dancing which functions as a sign of an overflowing expression of joy and joy from the ancestors who come to resemble the bodies of their grandchildren.

Nvg4-Mosalonde is a smooth processional movement with gentle dancing which functions as a sign of an overflow of sad and serene feelings to send the ancestors home when the balia ritual procession is over.

\section{Conclusion}

The conclusion of the function of nonverbal signs in balia ritual consists of equipment, attribute, instrument, color, and movement. The balia ritual equipment consists of six sign functions, namely (1) symbol-qualisign, (2) rhematic symbol, (3) symbol-dicent sign, (4) inconicsinsign, (5) dicent sign, and (6) symbol-sinsign. The attribute of the balia ritual consists of two sign functions, namely (1) symbol-sinsign and (2) icon-sinsign. The balia ritual instrument consists of three sign functions, namely (1) icon-qualisign-inconicsinsign, (2) qualisign-inconicsinsign, and (3) symbol-inconicsinsign. The color of the balia ritual consists of two sign functions, namely (1) icon-symbolqualisign and (2) symbol-qualisign. In the ritual movement of balia consists of one sign function, namely rhematic symbol-iconic sinsign.

\section{References}

Ali, M. Dkk (2000) Upacara Adat Balia Suku Kaili.Palu: Depdiknas-Pembinaan Permuseuman Sulteng.

Budianto, Irmayanti M (2001) “Aplikasi Semiotik pada Tanda Nonverbal” dalam Bahasa Pelatihan Semiotika. Jakarta: Pusat Penelitian Kemasyarakatan dan Budaya Lembaga Penelitian Universitas Indonesia. 
Budiman, Manneke (2001) "Semiotika dalam Tafsir Sastra: Antara Riffaterre dan Barthes" dalam Bahasa Pelatihan Semiotika. Jakarta: Pusat Penelitian Kemasyarakatan dan Budaya LP-UI, hlm. 20-31.

Budiman, Kris (1999) Kosa Semiotika. Yogyakarta: LKIS

Cassirer, Ernest. (1987)Manusia dan Kebudayaan, Sebuah Esei Tentang Manusia. Jakarta: Gramedia

Cobley, Paul dan Litza Janz (1999) Introduction Semiotics. New York: Icon Books-Totem Books

Christomy, Tommy (2001) "Pengantar Semiotik Pragmatik Peirce: Nonverbal dan Verbal" dalam Pusat Penelitian Kemasyarakatan dan Budaya Lembaga Penelitian Universitas Indonesia, 'Bahan Pelatihan Semiotika', hal: 7-14.

Creswell, J.W. (2016) Recearch Design; Pendekatan Metode Kualitatif, Kuantitatif, dan Campuran- Edisi 4: Yogyakarta: Pustaka Pelajar

Cummings, Louise (2007) Pragmatik, Sebuah Perspektif Multidisipliner. Yogyakarta: Pustaka Pelajar

Danandjaya, James (2007) Folklor Indonesia. Jakarta: Grafiti

Derrida, Jacques (1992) Acts of Literature. Derek Artridge (ed.) New York: Routledge

Evans, Donna (2003), Kamus Kaili-Ledo-Indonesia-Inggris, Edisiperdana: Sulawesi Tengah: Dinas Kebudayaan dan Pariwisata

Hayakawa, S.I. (1996) "Simbol-simbol” dalam Deddy Mulyana dan Jalaluddin Rakhmat (ed.). Komunikasi Antarbudaya: Panduan Berkomunikasi dengan Orang-Orang Berbeda Budaya. Bandung. Remaja Rosdakarya, hlm. 96-104.

Ihromi, T.O. (2016) Antropologi Budaya. Jakarta: Pustaka Obor Indonesia

Jauhari, Heri, (2018) Folklor, Bahan Kajian Ilmu Budaya, Sastra, dan Sejarah. Bandung: YramaWidya

Levinson C, dan Gumperz J (1996) Rethinking Linguistic Relativity. Cambridge University Press

Masyhuda, M. (1983) Ritual balia di Sulawesi Tengah.Palu: YayasanKebudayaan Sulawesi Tengah SeksiPenerbitan

Nadar, F.X. (2013) Pragmatik dan Penelitian Pragmatik. Yogyakarta: GrahaIlmu

Silverstein, Michael. (1993) “Metapragmatic discourse and metapragmatic function”. In John A. Lucy (ed), pp. 33-58.

Staehr, Andreas (2014) Urban Language and Literacies, Metapragmatic Activities on Facebook: Enrigisterment across written and spoken language practices. Unversity of Copenhagen.

Urban, G (2006) Metasemiosis and Metapragmatics. Philadelphia: University of Pennsylvania.

Verschueren, Jef. (2002) "Notes on the role of metapragmatik awarness in language use. In Benicot J, Trognon A, Guidetti M \&Musiol M (eds) Pragmatique et psychologie”. Nancy Presses Universitaires de Nancy. 5772.

Yule, George. 2014. Pragmatik. Diterjemahkan oleh Indah Fajar Wahyuni. Yogyakarta: Pustaka Pelajar. 